\section{Recorking the mighty oak in Provence}

Cork oak (Quercus suber L.) is an important tree species in the Mediterranean region with a total production of 250000 tonnes of cork per year. Production is threatened by the lack of natural regeneration, overgrazing, climate change, deforestation and fire. Since as early as 1990, there has been an increased interest in cork oak regeneration in the region.

Cork oak is a medium sized evergreen oak tree that grows in southwestern Europe and northwest Africa. The tree forms a corky bark that, over time, can develop considerable thickness, which is harvested every 9-12 years as cork. During harvest, the tree remains standing while large sections of its outer bark are cut and peeled from the tree. A new layer of the tree regrows making cork a renewable resource.

A working group has been established to build partnerships between cork producers in several Model Forests in the Mediterranean region, including Spain, Algeria, Morocco, France, Italy and Tunisia. The working group is addressing several areas of common

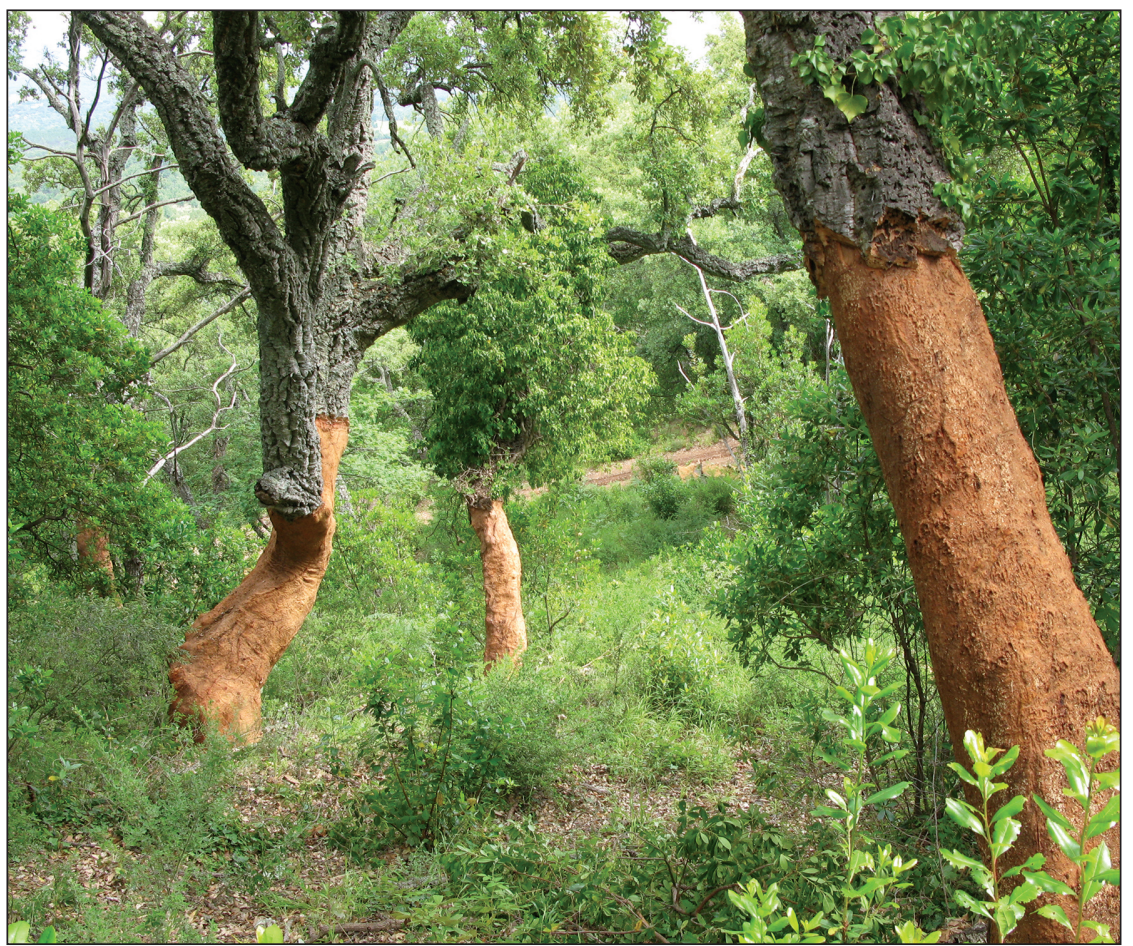

ship with the ASL Suberaie Varoise (http://www.suberaievaroise.com/), the associations of cork oak owners of the Maures' Forest in Provence.

\section{For more Information}

Report (French only) : http://www.sub eraievaroise.com/documents/CRFI NAL-JT2013.pdf

Contact: Ludivine Guy, Chargée de mission Forêt Modèle de Provence : ludivine.guy@foretmodeleprovence.fr

Mediterranean Model Forest Network : http://www.mmfn.info/sitio/index.php

Provence Model Forest : http://www. ofme.org/foretmodele-provence/ index.php

\section{Régénération du grand chêne- liège en Provence}

Le chêne-liège (Quercus suber L.) est une essence d'arbre importante dans la région méditerranéenne, avec une production totale de 250000 tonnes de liège par an. La production de chêneliège est menacée par l’absence de régénération naturelle, le surpâturage, les changements climatiques, le déboisement et les incendies. Depuis le tout début des années 90, il y a un intérêt accru concernant la régénération du chêne-liège dans la région.

Le chêne-liège est un chêne à feuillage persistant de taille moyenne qui pousse dans l'Europe du Sud-Ouest et l'Afrique du Nord-Ouest. Larbre produit une écorce liégeuse qui, au fil du temps, peut prendre une épaisseur considérable et qui est récoltée tous les neuf à 12 ans pour son liège. Lors de la récolte, l'arbre reste dressé alors que de grandes sections de l'écorce externe sont coupées et enlevées de l'arbre. Une nouvelle couche de larbre pousse de nouveau, faisant ainsi du liège une ressource renouvelable.

Un groupe de travail a été mis sur pied afin d’établir des partenariats entre les producteurs de liège dans plusieurs forêts modèles de la région méditerranéenne, notamment l'Espagne, l'Algérie, le Maroc, la France, l'Italie et la Tunisie. Le groupe de travail aborde plusieurs 


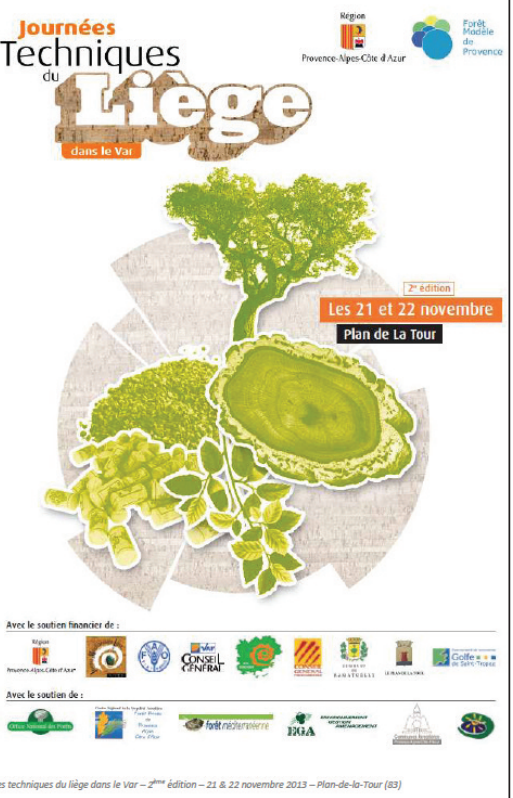

secteurs de préoccupations communes concernant la production et la commercialisation du liège, tout en ayant un intérêt principal pour l'établissement d'une banque de données sur les forêts de chênes-liège. En novembre 2013, la Forêt Modèle de Provence a organisé une conférence avec d'autres pays méditerranéens afin de mettre en commun leurs méthodes de régénération et leurs outils de développement ayant porté fruit. Un rapport technique de 140 pages résume chaque présentation en détail. Également, la Forêt Modèle de Provence a mené des recherches approfondies sur différentes procédures techniques de restauration du chêne-liège, notamment les techniques et les pratiques exemplaires de récolte efficace.

Le projet de régénération du chêneliège se poursuivra cette année avec l'établissement d'un site pilote pour la régénération des forêts de chênes-liège. Le projet comprend la coupe à blanc et le dessouchage, la régénération naturelle et artificielle des glands de chêne, la plantation et l'installation de barrières protectrices contre la faune. Dans le cadre du projet, les promoteurs comptent également proposer des protocoles de régénération fiables pour les forêts de chênes-liège de la région. Le projet comprend également la mise en œuvre de nouvelles applications et utilisations pour le liège et lélaboration d'une stratégie de marketing.
Ce projet est géré en partenariat avec ASL Suberaie Varoise (http://www.suberaievaroise.com/) ainsi qu'avec les associations de producteurs de chênes-liège de la forêt des Maures en Provence.

Pour obtenir de plus amples renseignements

- Rapport (en français seulement) : http://www.suberaievaroise.com/docu ments/CRFINAL-JT2013.pdf

- Personne-ressource : Ludivine Guy, chargée de mission, Forêt Modèle de Provence : ludivine.guy@foretmodeleprovence.fr

- Réseau méditerranéen de Forêts Modèles : http://www.mmfn.info/ sitio/index.php

- Forêt Modèle de Provence : http://www.ofme.org/foretmodeleprovence/index.php

\section{llomansti Model Forest facilities cross-border assessment of fire risk database}

The Karelian landscape is a combination of forests, mires (bogs) and waterways that spans the border between Finland and Russia. It is where the Ilomantsi Model Forest is located, which shares a $100 \mathrm{~km}$ long border with the Russian Republic of Karelia.

When the idea of the Model Forest was first proposed, the partners recognized that landscape decisions on the Finnish side could only be implemented in conjunction with decisions made on the Russian side. They recognized that landscape planning approaches in Finland and Russia were significantly different and those differences reduced overall sustainability in the region.
Moreover, land ownership structures and cross-border communications and cooperation issues made it a challenge to coordinate practices and plans.

The Model Forest saw an opportunity to create connectivity to produce ecologically meaningful results, promote sustainable landscapes and derive economic benefits through projects such as the identification of the new methods and techniques for landscape assessment, mapping high conservation value forests using remote sensing data, and showing the advantages for FSC group certification for main landowners in Ilomantsi. Another Model Forest project has been to facilitate a crossjurisdictional assessment of fire risk. One of the challenges was to reconcile the different measurement and classification systems used by both countries. The aim of the study was to analyze cross-border forest fire risks and to test the possibilities for joint data dissemination.

On the Russian side there are large tracts of forest with little fragmentation, few roads and almost no fuel management procedures. The Finnish side is characterized by smaller more fragmented forest tracts, higher road density and intensive forest management operations. Most importantly, the management approaches were substantively different and did not allow for appropriate data and measurement comparisons. By spatially identifying the location and size of potential fire risk and adopting complementary measurement units, researchers were able to map and classify, on both sides of the border, areas of high-medium and low fire risk.

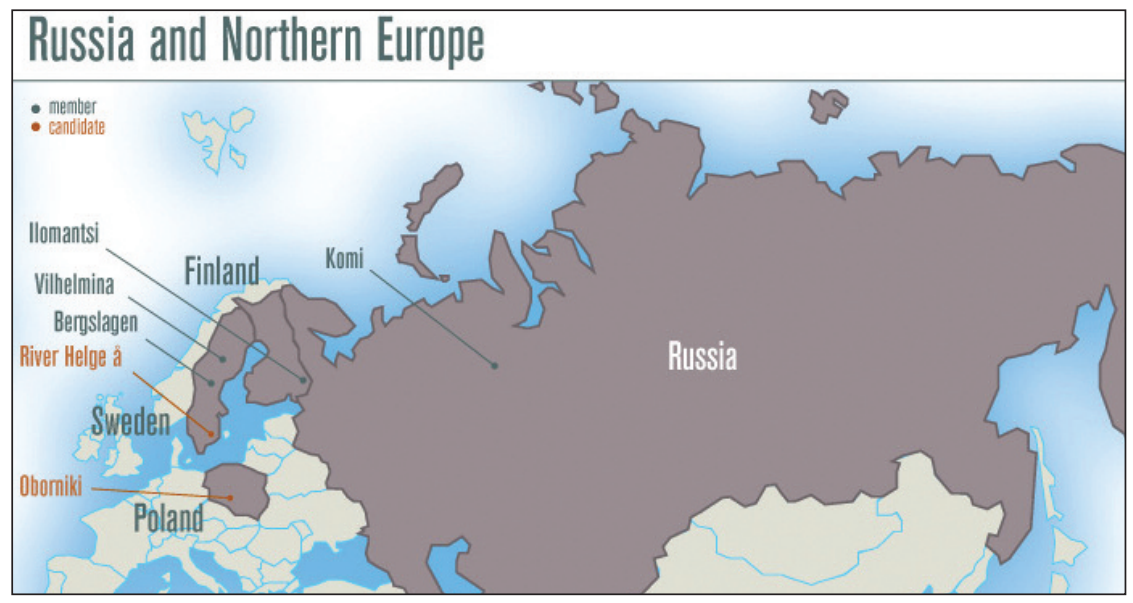

Current and proposed model forests in Russia and Northern Europe 


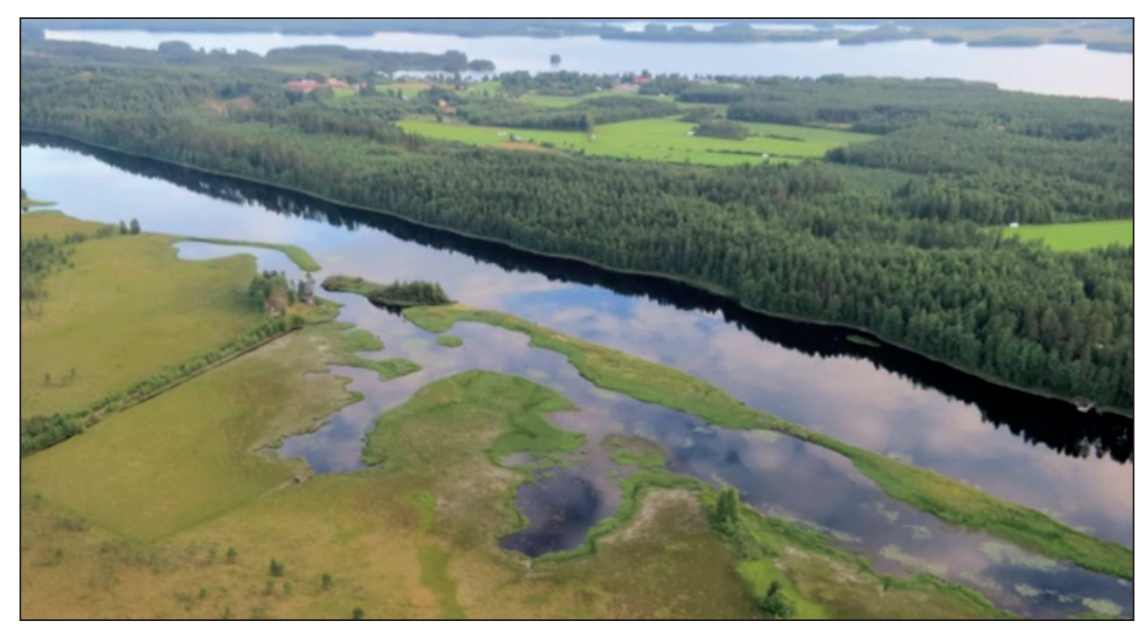

One of the many waterways of the Karelian landscape

This information helps in fuel management and harvesting regimes.

While the impulse to form a Model Forest differs from place to place, all Model Forests are usually created to address a significant issue or challenge identified on the landscape. The creation of the Ilomantsi Model Forest was a response to impacts of globalization, climate change, and the more intensive use of natural resources in the area. Its work has led to increased cross-border cooperation, new economic opportunities and enhanced protection of the landscape.

\section{For more information}

- Ilomansti Model Forest Web site: http://www.modelforest.fi/en/

- Baltic Landscape project page: http://www.skogsstyrelsen.se/en/Projektwebbar/Baltic-Landscape/

- Cross-border fires risks database presentation: http://www.metla.fi/ tapahtumat/2013/metsapalot/pdf/lop atin.pdf

- Karlands Project webpage: http:// www.kareliabiosphere.fi/in-english/ br-activities-and-projects/ projects/sustainable-karelian-landscapes/

Évaluation de la base de données sur les risques d'incendie concernant les installations transfrontalières de la Forêt modèle llomansti

Le paysage carélien se compose d'une combinaison de forêts, de bourbiers (tourbières) et de voies navigables qui sétendent le long de la frontière entre la Finlande et la Russie. C'est l'emplace- ment où se situe la Forêt modèle Ilomantsi, qui partage sur $100 \mathrm{~km}$ de long la frontière avec la République russe de Carélie.

Lorsque l'idée de la Forêt modèle a d’abord été proposée, les partenaires ont reconnu que les décisions touchant le paysage du côté finnois ne pouvaient être appliquées que conjointement avec celles qui étaient prises du côté russe. Ils ont reconnu que les approches en matière de planification du paysage en Finlande et en Russie étaient nettement différentes, et ces différences réduisaient la durabilité générale dans la région. De plus, les structures de propriété foncière de même que les communications transfrontalières et les enjeux de coopération rendaient difficile d'effectuer la coordination des pratiques et des plans.

La Forêt modèle a constaté la possibilité détablir une connectivité afin de produire des résultats significatifs sur le plan écologique, de promouvoir les paysages durables et de retirer des avantages économiques dans le cadre de projets comme létablissement de nouvelles méthodes et techniques pour lévaluation des paysages, la cartographie des forêts de haute valeur pour la conservation à l'aide des données de télédétection, et l'indication des avantages concernant la certification de groupe du FSC pour les principaux propriétaires fonciers à Ilomantsi. Un autre projet de la Forêt modèle vise à favoriser une évaluation pangouvernementale du risque d'incendie. L’un des défis consistait à rapprocher les différents systèmes de mesure et de classification utilisés par les deux pays. Létude avait pour but d'analyser les risques de feu de forêt transfrontaliers et dévaluer les possibilités de diffusion de données conjointe.

Du côté russe, il y a de vastes étendues de forêt avec une fragmentation réduite, peu de routes et presque aucune procédure de gestion des combustibles. Le côté finnois se caractérise par des étendues de forêt plus petites et plus fragmentées, une densité des chemins forestiers plus élevée et des opérations de gestion forestière intensives. Surtout, les approches de gestion étaient nettement différentes et ne permettaient pas deffectuer des comparaisons des données et mesures appropriées. En identifiant spatialement l'emplacement et lampleur du risque d'incendie éventuel et en adoptant des unités de mesure complémentaires, les chercheurs ont été en mesure détablir la cartographie et la classification, des deux côtés de la frontière, des secteurs de risque d'incendie moyen à élevé et faible. Ces données contribuent à l'établissement des régimes de gestion des combustibles et dexploitation forestière.

Bien que l'impulsion de créer une forêt modèle diffère d'un endroit à l'autre, toutes les forêts modèles sont habituellement créées afin d'aborder un enjeu ou un problème important cerné dans le paysage. La création de la Forêt modèle Ilomantsi fut en réaction aux répercussions de la mondialisation, au changement climatique et à l'utilisation plus intensive des ressources naturelles dans la région. Ses travaux ont entrainé une coopération transfrontalière accrue, de nouvelles possibilités économiques et une protection accrue du paysage.

Pour obtenir de plus amples renseignements

- Site Web de la Forêt modèle Ilomansti : http://www.modelforest.fi/en/ - Page Web sur le projet des paysages baltiques : http://www.skogsstyrelsen. se/en/Projektwebbar/Baltic-Landscape/

- Présentation de la base de données sur les risques d'incendie transfrontaliers : http://www.metla.fi/tapahtumat/2013/metsapalot/pdf/lopatin.pdf - Page Web sur le projet Karlands : http://www.kareliabiosphere.fi/ in-english/br-activities-and-projects/ projects/sustainable-karelian-landscapes/ 


\section{Gaining a perspective on world forestry}

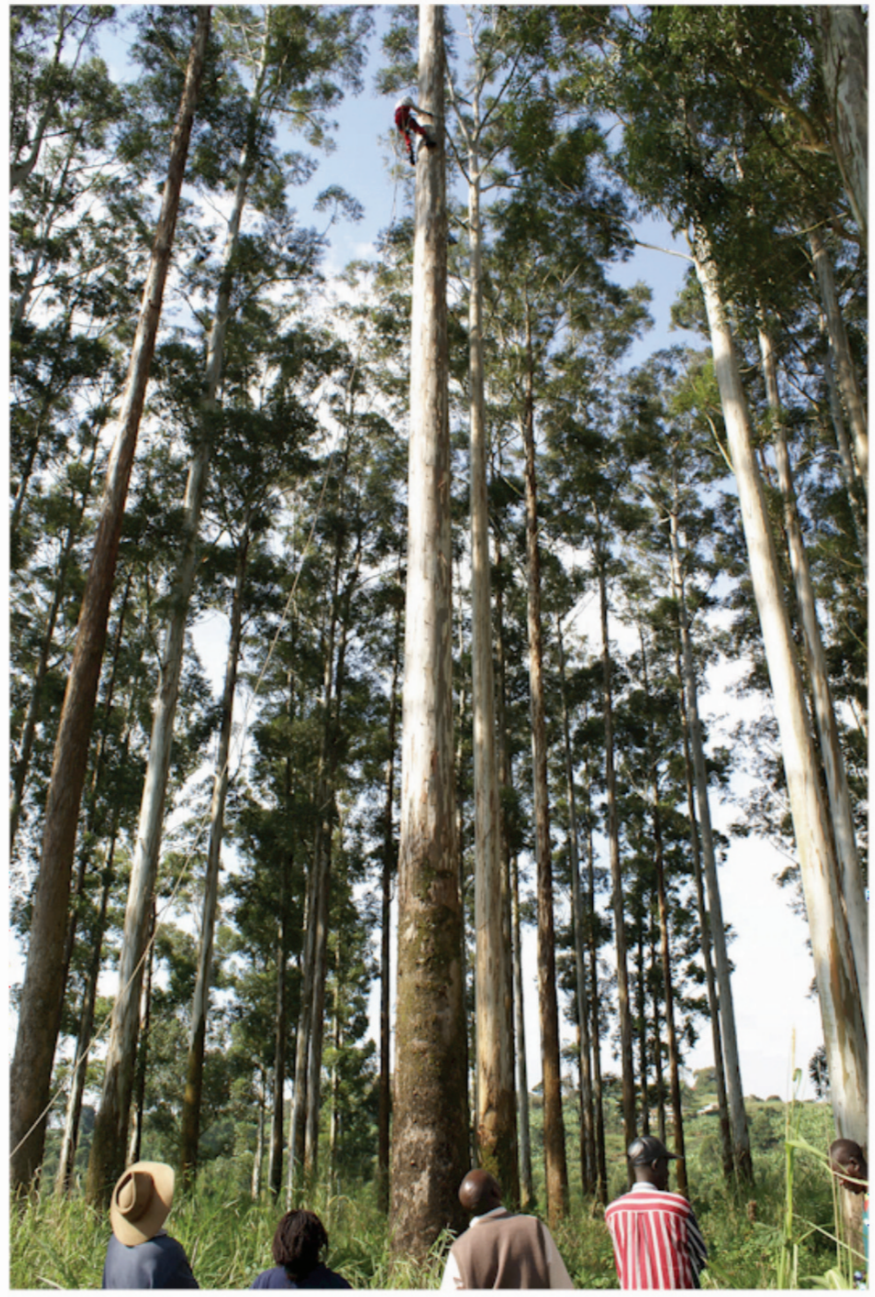

The Commonwealth Forestry

Association is the world's leading professional forestry association

focused on international forestry. We:

- Publish world-class science in our peer-reviewed forestry journal, the International Forestry Review.

- Facilitate networking of professional members and organisations and exchange of knowledge via our quarterly newsletter, website, Facebook page and Twitter feed.

- Encourage professional excellence and promote career development using a range of awards, such as the Queen's Award for Forestry, the Young Forester Award and the Young Scientist Research Award.

- Carry out a range of specific projects in the field that have been identified by our membership.

- Promote capacity building by helping to organise training courses, workshops, and conferences.

We are also the home to the secretariat for the Standing Committee on Commonwealth Forests, which is comprised of representatives of all of the forest departments from throughout the Commonwealth. The committee provides a unified voice on forestry matters to governments and international meetings and organises the Commonwealth Forestry Conference, an event which takes place every four years.

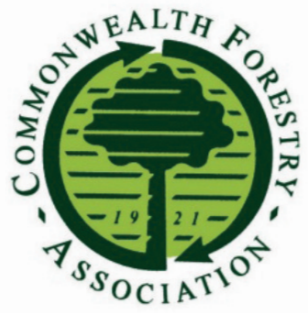

If you join us you'll be supporting future generations of foresters who work on our behalf to manage the environment of trees and forests. Membership is open to all including citizens of non-Commonwealth countries and Commonwealth countries.

Find out more at www.cfa-international.org 